\title{
No Lessons Learned: A Critique of the Queensland Local Government Reform Commission Final Report
}

\author{
Brian Dollery, Chong Mun Ho and James Alin ${ }^{1}$
}

\begin{abstract}
On 17 April 2007 the Queensland government established a Reform Commission to consider the compulsory amalgamation of local councils. On 27 July 2007 the Commission recommended a program of compulsory amalgamation that would reduce the number of local councils from 157 to 73 . These recommendations were passed into law amidst great acrimony in the early hours of 10 August. This paper provides a critical evaluation of the arguments for amalgamation presented by the Commission in the light of the scholarly literature on local government mergers.
\end{abstract}

\section{Introduction}

The new millennium has witnessed a period of severe financial distress in local government in all Australian state and territory jurisdictions, as attested by numerous national and state-based inquiries into the financial sustainability of local councils. ${ }^{2}$ Queensland local government has not been immune to these problems. In 2004, the Local Government Association of Queensland (LGAQ) developed a program to deal with financial and other pressures confronting local councils in that state. In order to generate debate, a Discussion Paper entitled Size, Shape and Sustainability of Queensland Local Government was issued on 3 March 2005 and a Special Conference of the LGAQ held in Brisbane in early June 2005. The initial outcome was the Communiqué advocating a 'comprehensive

\footnotetext{
1 Brian Dollery is Professor of Economics and Director, Centre for Local Government at the University of New England, Armidale, New South Wales. Chong Mun Ho is Associate Professor in the School of Science and Technology, Universiti Malaysia Sabah, Kota Kinabalu, Malaysia. Dr James Alin is in the School of Business and Economics, Universiti Malaysia Sabah, Kota Kinabalu, Malaysia. Brian Dollery would like to acknowledge the financial support provided by Australian Research Council Grant DP0770520. The authors would like to record their gratitude to the Editors and two anonymous referees for helpful comments on an earlier draft of the paper. Corresponding author: Brian Dollery, Email: bdollery@une.edu.au

2 See the Commonwealth Grants Commission (CGC) (2001); Commonwealth House of Representatives Standing Committee on Economics, Finance and Public Administration's (Hawker Report) (2004) Rates and Taxes: A Fair Share for Responsible Local Government; the PriceWaterhouseCoopers (PWC) (2006) National Financial Sustainability Study of Local Government report; the South Australian Financial Sustainability Review Board's (FSRB) (2005) Rising to the Challenge report; the Independent Inquiry into the Financial Sustainability of NSW Local Government's (2006) Final Report entitled 'Are Councils Sustainable?'; the Western Australian Local Government Association's (WALGA) (2006) Systemic Sustainability Study: In Your Hands - Shaping the Future of Local Government in Western Australia Inquiry; and the Local Government Association of Tasmania's (LGAT) (2007) A Review of the Financial Sustainability of Local Government in Tasmania.
} 
reform blueprint', followed immediately by a 'ten point Action Plan'. This proposal was formally endorsed by the Queensland Minister for Local Government and Planning. The Action Plan set out a reform program in the form of the Size, Shape and Sustainability (SSS) Review Framework, sustainability indicators, 'options for change', 'Independent Review Facilitators', and financial arrangements for Queensland government support of \$25 million. The mechanics of the reform process were embodied in the Size, Shape and Sustainability: Guidelines Kit (LGAQ 2006). In essence, the SSS process involved cooperation and collaboration between state government agencies and local councils on a scale unrivalled in the history of Australian local government reform.

The SSS review process was still ongoing on 17 April 2007 when the Queensland government suddenly announced that it had forsaken the SSS process in favour of a program of forced amalgamation. In the guise of a Local Government Reform Program, the Queensland government appointed a Local Government Reform Commission to make recommendations on compulsory local council mergers by August 2007 to enable the election of new councils on 15 March 2008. ${ }^{3}$ The official rationale for the abandonment of the SSS process was explained in Local Government Reform: A New Chapter for Local Government in Queensland (Department of Local Government, Planning, Sport and Recreation (DLGPS\&R)) (2007) and effectively amounted to a claim that local councils had not proceeded with sufficient haste and vigour in pursuing the SSS program. This document has been attacked as deficient in both concept and fact (see Dollery et al. (2007b) and LGAQ (2007)).

3 The Terms of Reference for the Reform Commission were published under section 159U of the legislation on 19 April 2007 as follows:

‘159U Terms of reference:

(1) This section states terms of reference for the reform commission in performing its functions.

'(2) The reform commission must consider the grouping of like communities of interest to maintain the social fabric and character of communities and areas of the State, and in particular, must consider - (a) review areas established under SSS review processes; and (b) boundaries of areas covered by the regions for which regional planning advisory committees have been established under the Integrated Planning Act 1997.

(3) The reform commission's recommendations must be directed at - (a) consolidating, to the extent practicable, regional natural resource management areas, including for example water catchment areas, and environmental areas, including for example, coastal wetlands; and (b) creating local governments with improved financial sustainability.

(4) In making a recommendation for creating a new local government area from 2 or more existing local government areas, the reform commission must give preference, to the extent practicable, to including all of the existing local government areas in the new area rather than parts of the existing areas.

(5) The reform commission must identify options for community representation that reflect the diversity of the State's regions and that promote representation of discrete communities.

'(6) In making its recommendations for new arrangements, the reform commission must identify any issues requiring further consideration for successfully establishing the new arrangements.' 
After a mere two months of deliberations, the Reform Commission released its Final Report entitled Report of the Local Government Reform Commission (State of Queensland (Local Government Reform Commission)) (2007) on 27 July 2007. ${ }^{4}$ The Final Report comprised two volumes: Volume 1 set out the arguments for radical structural reform in Queensland, while Volume 2 provided details of the new recommended local government areas developed in the Final Report. The Final Report recommended the number of local councils be compulsorily reduced from 157 to just 73 organisations. When it is noted that no changes at all are proposed to 37 councils, then the extreme nature of the Reform Commission is placed in even greater relief. Some of the more controversial recommendations included the forced amalgamation of the Noosa Shire Council with Maroochy Shire and Caloundra Shire, leading to fears that the new entity would have a 'development bias', that would destroy the beauty of the Noosa area, as well as the compulsory merger of Crows Nest, Rosalie, Jondaryan, Millmerran, Pittsworth, Clifton and Cambooya Shires with the large regional Toowoomba City Council, which many felt endangered the continued existence of many small towns surrounding Toowoomba.

The Recommendations of the Reform Commission were passed into law in the Queensland Parliament in the early hours of 10 August 2007 amidst great public controversy and rancour. A most unusual feature of this legislation was the inclusion of stiff monetary penalties to be imposed on elected representatives who attempted to hold referenda to test public opinion on forced mergers in their council jurisdictions. ${ }^{5}$

Given the radical nature of the Queensland compulsory amalgamation program, as well as the haste with which decision-making proceeded, there is an urgent need to evaluate the arguments in favour of forced mergers presented in the Final Report of the Queensland Reform Commission. Accordingly, this paper seeks to assess the substantive arguments presented in the Final Report against the background of developments in contemporary Australian local government and the relevant scholarly literature in the area.

\footnotetext{
4 The Reform Commission comprised seven members, assisted by administrative staff and analysts from the Queensland government bureaucracy. Commission members were Commission Chairperson Bob Longland (a former Electoral Commissioner for Queensland); Sir Leon Hielscher (Chair of the Queensland Treasury Corporation); Terry Mackenroth (former Deputy Premier of Queensland and a member of the Queensland Parliament from 1977 to 2005); Di McCauley (former Queensland parliamentarian from 1986 to 1998 and former Queensland Minister for Local Government and Planning); Tom Pyne (former President of the Local Government Association of Queensland); and Bob Quinn (former Leader of the Queensland Liberal Party). Administration Commissioner was Kevin Yearbury (former Director-General of the Queensland Department of Local Government and Planning).

5 The attempt by the Queensland government to prevent local referenda has led to controversial involvement by the former federal government to fund local plebiscites on amalgamation, apparently inspired by political motives (Marris 2007). The Queensland government responded by withdrawing the punitive elements in its legislation, but nonetheless still proceeding with the amalgamation program. At the time of writing, plebiscites had been held in numerous local council jurisdictions, with overwhelming public opposition to the structural reform program.
} 
The paper itself is divided into three main parts. Section 2 sets out the case for compulsory amalgamation presented by the Commission in its Final Report, with only some limited critical asides. Section 3 considers the validity of these arguments. The paper ends with some brief concluding remarks in section 4 .

\section{The Reform Commission's Case for Forced Amalgamation}

The Reform Commission presents its case for forced amalgamation in Chapters 3 and 4 of its Report of the Local Government Reform Commission (State of Queensland (Local Government Reform Commission)) (2007).

Discussion in Chapter 3 is organized under six main headings: 'analysis'; local government capacity; 'social, economic and environmental factors'; ' community of interest'; 'financial sustainability'; and 'boundaries'. Under the analysis heading, the Commission simply lists its objectives as set out in its Terms of Reference and outlines the 'range of data sources' (p.37) it employed. The latter is significant in the sense that no material is specified dealing with local government reform elsewhere in Australia or indeed abroad. This sets the tone for a highly 'Queensland-centric' mode of analysis.

The remaining five headings deal with what we can call 'substantive' criteria. The first substantive criterion invoked by the Commission consists of the capacity of local government to deliver services, undertake planning and exercise sound governance' (p.38). In so doing, the Commission sought to assess how structural reform through amalgamation 'would improve local government's ability to deliver services, undertake environmental, social and economic planning, and provide local government with the capacity to better manage risk' (p.38). The Commission found local councils throughout Queensland are presently 'struggling' to meet the demands placed on them and battling to compete for scarce administrative and technical skills in a highly competitive labour market. From this diagnosis, the Commission concluded that 'stronger more robust local governments' will better be able to overcome these challenges.

The analysis of local government capacity goes on to consider 'structural barriers' that 'impede' service provision and effective growth management and development planning. Six illustrative examples are provided: (i) Population growth in areas that cross local council borders should be 'managed on a regional basis', such as the Sunshine Coast; (ii) the existence of 'multiple' local council planning systems raises the 'complexity' of managing regional development, like the Darling Downs; (iii) current boundaries that create 'artificial' barriers between communities, such as boundaries that divide single residential areas; (iv) 'duplication', and 'complexity', such as Townsville/Thuringowa; (v) numerous small councils in a 'compact' spatial zone that cannot 'capture and manage' economic development, like North Burnett; and (vi) 'donut' councils that 'impede optimal service delivery'. 
A discussion of the 'costs and benefits' associated with amalgamation ensues, which forms the central thrust of the case for forced mergers in the Commission's deliberations. In a candid admission, the Commission concedes that it has not attempted to quantify these costs [of amalgamation] in respect of the recommendations it makes' (p.38), despite acknowledging that significant costs exist. Instead, the Commission was 'guided' by the outcomes of previous Queensland local mergers in the 1990s (Cairns, Ipswich, Mackay, Warwick and Cooloola), despite the fact that no formal assessments have ever been made of the consequences of these amalgamations; the Commission argued that in all cases', these councils have 'emerged as stronger administrations' that 'better represent their communities'. In addition, the Commission relied on SSS appraisals from four councils (Crows Nest/Rosalie and Goondiwindi/Waggamba). These reviews identified costs attendant on mergers that included a decline in Financial Assistance Grants, 'disruptions' to service provision during the implementation of amalgamation, and outlays on 'integrating council systems'. However, these same SSS reviews predicted various benefits to amalgamation, not least (a) a 'larger resource base', better infrastructure management and enhanced capacity; (b) scale economies (that are not identified by service type); (c) unquantified and unspecified 'savings' that can 'fill gaps in middle management' thereby improving operational efficiency; cost savings from asset 'rationalisation'; and (d) 'better planning and infrastructure delivery across growth areas' (p.39).

From this limited evidence drawn exclusively from Queensland, the Commission felt able to generalize the benefits of structural reform into main four categories: (a) economies of scale; (b) more efficient infrastructure delivery; (c) more skilled staff; and (d) improved financial governance and standards implementation. However, the Commission immediately (and perhaps unwittingly) undercuts these assertions by observing that the costs incurred by, and the benefits which accrue to amalgamated councils will largely be dependent decisions the new local governments make during the implementation phase', depending on how these new organizations expend the 'dividends' derived from amalgamation. It is important to stress that in its evaluation of the costs and benefits of council mergers, the Commission completely ignores any evidence that may be gleaned from Victoria, South Australia and New South Wales, all of which have undergone structural reform over the past two decades, as well as the wealth of material available from abroad. ${ }^{6}$

The second main criterion applied by the Commission consisted of 'social, economic and environmental factors', especially in the context of 'regional communities of interest'. In particular, the Commission identified six main

6 An anonymous referee observed that 'as an outsider, it seems almost unbelievable that a government commission could make such sweeping recommendations without apparently even attempting to marshal any evidence'. We concur with this view. 
'challenges' confronting regional Queensland local government over the next 20 years, as follows: (a) Maintaining the viability of communities in Western Queensland; (b) dealing with the transformation of economic activity away from traditional agriculture in Western Queensland; (c) coping with the problems presented by the rapid increase in mineral extraction and its need for infrastructure; (d) growth management in regional centres; (e) managing 'tree-change' and 'sea-change' migration flows; and (f) growth management in South East Queensland. While none of these factors are addressed further, the Commission simply observed that it 'has sought to balance the specific (social, economic and environmental) aspirations of local communities' (presumably as expressed in submissions to the Commission) ' with the regional economies it sees emerging over the next 20 to 30 years' (p. 40). How this was done is left to the imagination of the reader.

The third major criterion resides in 'community of interest' as defined in Local Government Regulation 2005, with the proviso that the Commission should try to avoid amalgamating parts of existing areas and instead incorporate whole local government areas together. In its discussion, the Commission went into some detail over the difficulties involved in determining community of interest in practice and noted the 'passion' with which people experienced a 'sense of place' associated with a current local government area. However, it nonetheless 'separated the issue of identification with a particular locality, from that of a broader community of interest, apparently on the basis that instances exist in Queensland where 'distinctive communities continue to thrive within existing local government boundaries' (p.41). How the Commission has proceeded is not explained.

The fourth main criterion guiding the Commission is 'financial sustainability' - the chief motivating force for the amalgamation program according to the DLGPS\&R (2007) Local Government Reform: A New Chapter for Local Government in Queensland, which set out the rationale for the whole reform process (Dollery et al. 2007b; LGAQ 2007). It is thus little short of astounding that the Commission 'has not attempted to define a minimum level of financial sustainability for local government in Queensland' (p.42). The Commission observed that it relied on the Queensland Treasury Corporation's (QTC) Financial Sustainability Reviews, which are considered in Chapter 8 of its Final Report, despite the fact that not all councils had undergone QTC scrutiny prior to the Final Report - a matter the Queensland government used to justify abandoning the SSS program!

Two points are relevant in this regard. Firstly, of the 109 councils that had been reviewed by the QTC, 57 councils ( 52 per cent) were classified as 'moderate' in terms of financial sustainability, where moderate implies a 'high capacity to meet its financial commitments', and 28 (25.6 per cent) were designated as 'weak', where weak means an 'acceptable capacity to meet its financial commitments' 
(p.71). In other words, in the view of the QTC, these two groups of councils were not perceived as financially unsustainable! Secondly, the definition of financial sustainability in the Australian local government milieu has not only proved to be elusive, as attested by the state-based inquiries in South Australia, New South Wales, Western Australian and Tasmania cited earlier in this paper (see Dollery and Crase 2006), but also too narrow (Dollery et al. 2006a). The Commission seems to have overlooked these definitional difficulties altogether as a consequence of its exclusive use of Queensland literature.

The fifth and final criterion consists of local government boundary considerations to which we have already alluded. The Commission felt bound by its Terms of Reference to make recommendations for amalgamation that involved only whole local government areas rather than parts of local government areas.

A feature of contemporary debate over structural reform in Australian local government is the emphasis placed on alternative models of local government that can be implemented instead of amalgamation in any process of structural reform. For example, the LGAQ (2005, p.15) has composed a taxonomy that distinguishes between four conceptual models: 'Merger/amalgamation'; 'significant boundary change'; 'resource sharing through service agreements', in which one local authority will undertake specific functions such as waste management for other councils; and 'resource sharing thorough joint enterprise', in which municipalities combine their activities in a given service function in order to reap scale economies, such as official record keeping and storing. Similarly, Dollery and Johnson (2005) have proposed a sevenfold typology comprising existing small councils, ad hoc resource-sharing agreements, Regional Organizations of Councils, area integration or joint board models, the virtual local government model, the agency model and amalgamated councils. These theoretical models have been augmented by a growing literature on applied models of local governance, either in operation or under consideration (see Dollery et al. 2007a).

For this reason, the Queensland Reform Commission no doubt felt obliged to at least consider alternatives to forced amalgamation in its deliberations. Three alternative models are discussed in Chapter 4 of the Final Report: the 'multi-purpose joint local government' (MPJLG) model advocated by the LGAQ; shared service models; and regional alliances of local councils. On the basis of its deliberations, the Reform Commission apparently felt able to dismiss these three alternatives out of hand. The Commission concluded that:

While MPJLGs, shared services and alliances have been promoted in suggestions as alternatives to amalgamation, the Commission considers that they are inferior options. All the advantages nominated by advocates of these alternatives can be realized by amalgamated councils, with less bureaucracy and administration, 
and avoiding the complexity and delays that are an inevitable part of negotiating agreements with multiple councils. These approaches remain valid for use by accountable elected entities which can consider their applicability in addressing particular administrative, service delivery or contracting issues, not as a substitute for structural reform.

This conclusion is noteworthy for two main reasons. Firstly, the Commission did not even attempt to engage with the Australian literature on alternative models of local government, which includes empirical evidence on the actual outcomes of several models already in operation, such as the very successful Riverina Eastern Regional Organisation of Councils in New South Wales (Dollery et al. 2005) and the Walkerville model in South Australia (Dollery and Byrnes 2006), to cite but two examples. Put differently, the Commission is guilty of 'evidence-free' policy evaluation. Secondly, most alternatives to amalgamation are premised on the notion of retaining local democracy and local choice while at the same time combining those functions that exhibit significant scale economies, scope economies and other efficiency-enhancing attributes. In other words, the whole thrust of these models is to preserve local autonomy without any trade-offs associated with the size of the organisation. By not even considering local autonomy, local choice, local democracy and local 'voice' as a desirable 'public good' in its own right, the Commission misses the central objective of these models.

\section{Evaluation of the Arguments for Amalgamation in the Final Report}

Structural reform in the guise of enforced local council mergers has a very long history in Australian local government (Vince 1997). In an analysis of the debates that have surrounding various episodes of council consolidation, Dollery et al. (2006b, pp.139-55) have provided a detailed evaluation of both the theoretical and empirical arguments typically advanced for local government amalgamation in Australia. They identified seven main conceptual considerations that have been brought to bear on the problem: 'Optimum community size'; economies of scale; economies of scope; local government capacity; administration and compliance costs; the 'coincidence of municipal and natural boundaries'; and public-choice arguments. This taxonomy provides a useful framework for considering the merits or otherwise of the conceptual case for amalgamation presented in the Final Report of the Queensland Reform Commission. We will thus briefly consider each of these factors in turn.

\section{Optimum community size}

As we have seen, the Reform Commission placed a good deal of weight on the importance of 'regional communities of interest' especially in economic development, planning and other matters with a comparatively large spatial 
focus. This demonstrates that the Commission considered the 'region' to represent an optimal 'community size', rather than smaller local government areas. However, the Commission seems completely unaware that notions of optimum community size are not simply plucked from the air but derive from the theory of fiscal federalism pioneered by Oates (1972) and subsequently refined by legions of economists (Mueller 2003). The theory of fiscal federalism is centrally concerned with the question: which levels of government (national, state or local) should provide specific categories of public goods? The theoretical answer follows from Oates' (1972) correspondence principle: the size of a government should reflect the area of benefit of the goods it provides to its constituents. Each public good should thus be provided by the smallest (that is, lowest-level) government where there are no spatial externalities affecting adjacent areas.

This principle has direct implications for local government amalgamation. In the first place, Oates (1972) has demonstrated through the decentralisation theorem that if local preferences determine the composition of local service provision, then welfare gains accrue to society because preferences are never spatially uniform. Local service provision should thus be decided at the local level, implying the retention of small local councils, at least insofar as deciding the composition of local services. Secondly, if spillover effects exist contingent on the exercise of local choice, then either subsidies or taxes must compensate neighbouring jurisdictions, or decisions over the services generating externalities should be taken at a higher level of government. Demand-side considerations of this kind are precisely the reason that various alternative models of local government prescribe that services with a regional impact should be decided at the regional level, while supply-side considerations, like scale economies, lead to an analogous conclusion in these models. ${ }^{7}$

\section{Economies of scale}

Economies of scale refer to a decrease in per-unit cost of production as the quantity of output increases. As we have seen, in its Final Report the Commission made frequent appeal to scale economies by arguing that larger amalgamated councils would provide services more cheaply. This claim cannot be sustained for several reasons (Dollery et al. 2006b). Firstly, despite the recent expansion of Australian local government services to include more 'services to people' (Dollery et al. 2006c), Australian local councils still have a strong 'services to property' orientation in terms of the services they provide. However, despite the relatively narrow range of service provision, Australian municipalities

\footnotetext{
7 In addition to these arguments, we are indebted to an anonymous referee for pointing out that the Commission also ignored the empirical literature on the relationship between governmental decentralisation and economic growth, which suggests that decentralised local government boosts local economic growth. See, for instance, Brueckner (2006), Akai and Sakata (2002), Lin and Lui (2000) and Stansel (2005).
} 
nonetheless deliver an extensive range of services. Because these services are produced using entirely different processes, there is no a priori reason for different services to display the same cost characteristics. It follows that while council mergers will secure scale economies for some services, they will also capture diseconomies of scale in other services. Sancton (2000, p.74) has summarised this argument by observing that 'there is no functionally optimal size for municipal governments because different municipal activities have quite different optimal areas'.

Secondly, it is well known that scale economies are not relevant if service provision can be separated from service production through the 'purchaser-provider split', since scale economies only occur during the production phase (Oakerson 1999). Thus local councils too small to achieve scale economies can still reap these cost advantages by outsourcing to private firms, Regional Organizations of Councils, area integration models, and the like. In other words, council size need bear no relationship to scale economies.

Thirdly, in its adoption of the 'big is beautiful' perspective of local councils, the Commission alludes to the cost 'dividends' attendant upon scale economies in the proposed new larger councils. The Commission thus implicitly endorsed inter alia the findings of Stephen Soul (2000) in his influential doctoral thesis, which examined the effect of council size (as measured by population) on gross expenditure per capita, and concluded that increasing population yields a lower level of gross expenditure per capita up to a council size somewhere between 100,000 and 316,000 people, at which point 'scale diseconomies' begin. But the theoretical basis of this study has been shown to be badly flawed on the basis of pioneering work by Boyne (1995) ignored by Soul (2000) (Dollery et al. 2006b). In essence, Boyne (1995) has demonstrated that council size (as proxied by population) bears no relationship to scale economies, since population is linked to numerous other variables affecting expenditure.

Finally, the Commission apparently takes for granted that substantial scale economies exist in Australian local government. This presumption is unwarranted and ignores both Australian empirical evidence on economies of scale in local government (see, for instance, Byrnes and Dollery 2002) as well as empirical evidence abroad (see, for example, Bish 1971; 2000; Boyne 1998a; Duncombe and Yinger 1993; Hirsch 1968; and Rouse and Putterill 2005), which points to the fact that scale economies cease for many municipal functions for populations above 50,000 residents and many labour-intensive services exhibit diseconomies of scale. With regard to Australian local government, Byrnes and Dollery (2002, p.405) conclude that the lack of rigorous evidence of significant economies of scale in municipal service provision casts considerable doubt on using this as the basis for amalgamations'. 


\section{Economies of scope}

The Commission makes no reference at all to scope economies. Given the complete neglect of the literature outside of Queensland in the Final Report, this omission is unsurprising. However, given the potential significance of scope economies, this oversight is most unfortunate.

Scope economies arise where production functions facilitate the joint production of two or more services simultaneously. Under increasing returns to scope, joint production by one organization generates more output than separate production by two different organizations using the same quantity of input. Within Australian local government service provision, then, it is possible to identify four potential sources of scope economies and diseconomies in local council services: decreasing returns to inputs; jointness in inputs; jointness in outputs; and interactions between the processes of service provision. According to (Dollery and Fleming 2006), the most likely source of scope economies in Australian local government derives from jointness in inputs, which occurs where one input can be used in the production of more than one service. Municipal administrative functions, where the same functions can be used in more than one sphere of activity, are easy to identify. For instance, in the event of council amalgamation or council resource-sharing, centralized administrative inputs can be used to support various activities, thereby reducing costs. Despite the promise offered by scope economies, no empirical studies have yet investigated the phenomenon in the Australian local government context (Dollery and Fleming 2006).

\section{Local government capacity}

As we have seen, in its Final Report the Commission set great store on enhanced local council capacity as a positive consequence of its forced amalgamation recommendations. In particular, the Commission (State of Queensland 2007, p.39) held that local government capacity could be expected to improve in four main areas: better asset and infrastructure management; increased ability to 'attract and retain quality staff in key positions'; superior 'risk management and compliance with financial and other reporting requirements'; and improved growth management. While no conceptual or empirical evidence at all is presented in support of this claim, we contend that this assertion seems reasonable, especially in the context of small remote and rural councils.

In Australian Local Government Economics, Dollery et al. (2006b, pp.145-6) consider precisely the same argument:

A proposition sometimes advanced in the Australian debate over amalgamation is that larger councils tend to possess greater levels of administrative and other expertise, in part due to the fact that their size permits the employment of specialist skills that cannot be acquired readily 
by smaller municipalities. Given the increasing burden placed on Australian local government by its state and federal counterparts, through cost shifting and other activities, it is held that this confers a significant advantage on larger municipal units because it enables them to accomplish a wider and more complex range of tasks in a more efficient manner.

While adding the caveat that no empirical work has been undertaken on the issue in Australian, Dollery et al. (2006b, p.146) nonetheless argue that 'there seems to be considerable merit in this argument' since 'small regional and rural councils do struggle in terms of expertise and cannot always use consultants in an effective and prudent way'. However, they add that many alternative models to amalgamation can achieve the same outcomes since they too can 'pool their resources to acquire the skills in question, at no greater cost than to single and larger councils'.

\section{Administration and compliance costs}

Dollery et al. (2006b, p.148) observed that:

An additional argument often put forward in support of local government amalgamation is that larger consolidated councils economize on their direct costs of administration and the compliance costs imposed on individuals who participate in the municipal political process, [where] administrative costs include the compensation paid to elected and appointed officials and staff and the overheads (buildings, supplies, utilities, etc.) required to support those officials [and] compliance costs include the costs incurred by municipal voters to keep informed on issues and candidate positions and the potential cash and time of registering an opinion by participating in hearings, meetings, voting, and other activities.

In a nutshell, the argument holds that fewer local councils results in lower administration and compliance costs. This argument is analogous to claiming that scale economies exist in both administration and compliance.

With respect to administration costs, in its dismissal of alternatives to amalgamation in Chapter 4, the Commission asserted that large amalgamated councils would involve 'less administration and bureaucracy' and avoid 'complexity and delays' inevitable in cooperative arrangements between smaller councils. It did not address a comparison of administrative costs between consolidated councils and existing councils for non-shared functions. This is unfortunate because in the public administration literature a wealth of evidence exists that larger bureaucracies are less effective since (a) longer administrative hierarchies inhibit the efficacious transformation of policy decisions into policy action and (b) decision-making is further removed from situational knowledge and thus is less well informed (Hood 2000). The Commission also ignored a second 
possibility: reduced oversight costs incurred by the Queensland DLGPS\&R arising from far fewer local councils.

\section{Coincidence of municipal and natural boundaries}

The recent debate in New South Wales over council mergers in that state witnessed the development of an argument in favour of much larger local government areas that has come to be called 'eco-civic regionalisation' (Brunckhorst and Reeve 2006). In essence, this view is based on the notion that while 'ecology is forever', human settlement is transitory and therefore regional management strategies should ensure that ecologically homogeneous geographic areas should form the basis for the design of local government areas, rather than current and future patterns of human settlement.

In section 3.3 of Chapter 3 of its Final Report, the Reform Commission outlined the factors it took into account in determining the boundaries of local government areas, which included 'environmental' factors and 'community of interest'. These issues were considered exclusively in terms of human factors, such as economic development, growth management, mineral extraction, population migration, and the like, with the single exception of forestry as a potential 'greenhouse sink'. In other words, the Commission did not incorporate eco-civic regionalisation into its deliberations at all. This is fortunate since the extreme notion of eco-civic regionalisation not only completely ignores the costs of the massive restructuring it would entail, but cannot demonstrate why state government agencies cannot adequately manage environmental issues (Dollery and Crase 2004).

\section{Public-choice arguments}

The final category in the Dollery et al. (2006b) classification involves public-choice considerations. These arguments have been articulated by numerous scholars of local government, perhaps most notably Bailey (1999) and Boyne (1998a). In effect, they amount to a conceptual rebuttal of the notion that 'big is beautiful' by maintaining that large councils are less accountable and transparent and more complex than their smaller counterparts and thus less easily monitored by voters, who have less contact with elected representatives. It is also argued that smaller municipalities are much closer to constituents and thereby better informed than large councils. A second empirical string to the public-choice bow is that 'bigger is not better', since considerable evidence has demonstrated that small councils deliver services more cheaply (see, for example, Boyne 1992; 1998b).

As we have seen, the Final Report adopts precisely the opposite view to these public-choice considerations at both the conceptual 'big is beautiful' level and the empirical 'bigger is better' level. Apart from the fact that the authors of the Final Report cite no literature outside of Queensland, this can also perhaps be 
partially explained by the fact that the public-choice perspective examines local government effectiveness from a citizen's perspective rather than an organisational perspective.

\section{Concluding Remarks}

Following our analysis of the case presented by the Reform Commission in favour of drastic forced amalgamation in Queensland local government, what general conclusions can be drawn from the discussion? Three observations appear pertinent. In the first place, the analysis conducted in the Final Report falls in line with similar official reports prepared in other Australian states over a long period of time that invariably recommend compulsory mergers (Dollery et al. 2007b). Indeed, as we have seen, most of the arguments used by the Commission fit easily into the typology developed in Dollery et al. (2006b). We are thus obliged to reach the bleak conclusion that the Reform Commission seems to have learned nothing from the hard-won experience of other Australian states with structural reform.

A second feature of the Final Report resides in the fact that it completely ignores Australian and international literature on structural reform, as exemplified by the fact that no research undertaken outside of Queensland is even considered in the Final Report. It is as if Queensland exists in a separate dimension of the universe.

A third conclusion, intimately related to our first two observations, is that no empirical evidence is adduced to support the rosy view the Commission holds of amalgamation as a means of improving the effectiveness of local councils. Even a cursory recognition of developments in other Australian states would have obliged the Commission to take a much more dispassionate view. After all, the recent state-based inquiries into the financial sustainability of local councils in South Australia (2005), New South Wales (2006), Western Australia (2006) and Tasmania (2007), as well as the PWC (2006) National Financial Sustainability Study of Local Government, were all unanimous that structural reform most certainly did not represent a 'magic bullet' that could cure the financial ills of Australian local government. Indeed, the PWC found that local government both in states that had undergone large-scale amalgamation, like Victoria, South Australia and New South Wales, and states that had not experienced structural reform, like Western Australia and Queensland, continued to experience financial problems. In particular, local infrastructure across Australia was in such a parlous condition that only the injection of billions of dollars - far beyond the financial capacity of local government in all states and certainly light years away from savings attendant upon forced mergers in even the most optimistic - could remedy the situation. If structural reform in other states failed to remove financial unsustainability, why should it be expected to succeed in Queensland? 


\section{References}

Akai, N., and M. Sakata, 2002, 'Fiscal Decentralisation Contributes to Economic Growth: Evidence from State-Level Cross-Section Data for the United States', Journal of Urban Economics, 52(1), pp.93-108.

Bailey, S. J. 1999, Local Government Economics, Macmillan, London.

Bish, R. 2000, Local Government Amalgamations: $19^{\text {th }}$ Century Ideas for the $21^{\text {st }}$ Century, Howe Institute, Toronto.

Boyne, G. A. 1998a, Public Choice Theory and Local Government, Macmillan, Basingstoke.

Boyne, G. A. 1998b, ‘Bureaucratic Theory Meets Reality: Public Choice and Service Contracting in U.S. Local Government', Public Administration Review, 58(1), pp.81-97.

Boyne, G. A. 1995, 'Population Size and Economies of Scale in Local Government', Policy and Politics, 23(3), pp.213-22.

Boyne, G. A. 1992, 'Local Government Structure and Performance: Lessons from America', Public Administration, 70(2), pp.332-45.

Brueckner, J. 2006, 'Fiscal Federalism and Economic Growth', Journal of Public Economics, vol. 90, no. 4, pp.2107-20.

Brunckhorst, D., and I. Reeve, 2006, 'A Geography of Place: Principles and Application for Defining "Eco-civic" Resource Governance Regions', Australian Geographer, vol. 37, no. 2, pp.147-66.

Byrnes, J. D., and B. E. Dollery 2002, 'Do Economies of Scale Exist in Australian Local Government? A Review of the Research Evidence', Urban Policy and Research, vol. 20, no. 4, pp.391-414.

Commonwealth Grants Commission (CGC) 2001, Review of the Operation of Local Government (Financial Assistance) Act 1995, Australian Government, Canberra.

Department of Local Government, Planning, Sport and Recreation (DLGPS\&R) 2007, Local Government Reform: A New Chapter for Local Government in Queensland, DLGPS\&R, Brisbane.

Dollery, B. E., and J. D. Byrnes 2006, 'Alternatives to Amalgamation in Australian Local Government: The Case of Walkerville', Journal of Economic and Social Policy, vol. 11, no. 1, pp.1-20.

Dollery, B. E., and L. Crase 2006, 'A Comparative Perspective on Financial Sustainability in Australian Local Government', Working Paper 01-2006, Centre for Local Government, University of New England, Armidale. 
Dollery, B. E., and L. Crase 2004, 'A Critical Note on "Eco-Civic Regionalisation" as the Basis for Local Government Boundaries in Australia', Australian Geographer, vol. 35, no. 3, pp.289-300.

Dollery, B. E., L. Crase and J. Byrnes 2006a, 'Overall Local Council in Australian Local Government', Working Paper 02-2006, Centre for Local Government, University of New England, Armidale.

Dollery, B. E., L. Crase and A. Johnson 2006b, Australian Local Government Economics, UNSW Press, Sydney.

Dollery, B. E. and E. Fleming 2006, 'A Conceptual Note on Scale Economies, Size Economies and Scope Economies in Australian Local Government', Urban Policy and Research, vol. 24, no. 2, pp.271-82.

Dollery, B. E. and A. Johnson 2005, 'Enhancing Efficiency in Australian Local Government: An Evaluation of Alternative Models of Municipal Governance', Urban Policy and Research, vol. 23, no. 1, pp.73-85.

Dollery, B. E., A. Johnson, N. Marshall and A. Witherby 2005, 'ROCs Governing Frameworks for Sustainable Regional Economic Development: A Case Study', Sustaining Regions, vol. 4, no. 3, pp.15-21.

Dollery, B. E., N. Marshall and T. Sorensen 2007a, 'Doing the Right Thing: An Evaluation of New Models of Local Government Service Provision in Regional New South Wales', Rural Society (forthcoming).

Dollery, B. E., J. L. Wallis and P. Allan 2006c, 'The Debate That Had to Happen But Never Did: The Changing Role of Australian Local Government', Australian Journal of Political Science, vol. 41, no. 4, pp.553-67.

Dollery, B. E., J. L. Wallis and L. Crase 2007b, ‘Has the Queensland Government Policy Reversal on Local Government Amalgamation been Satisfactorily Justified?', Working Paper 09-2007, Centre for Local Government, University of New England, Armidale.

Financial Sustainability Review Board (FSRB) 2005, Rising to the Challenge, South Australian Local Government Association, Adelaide.

Hood, C. 2000, The Art of the State, Clarendon Press, Oxford.

House of Representatives Standing Committee on Economics, Finance and Public Administration ('Hawker Report') 2004, Rates and Taxes: A Fair Share for Responsible Local Government, Commonwealth of Australia, Canberra.

Independent Inquiry into Local Government Inquiry (LGI) ('Allan Report') 2006, Are Councils Sustainable? Final Report: Findings and Recommendations, NSW Local Government and Shires Association, Sydney.

Lin, J. Y., and Z. Lui 2000, 'Fiscal Decentralisation and Economic Growth in China', Economic Development and Cultural Change, 49 (1), pp.1-21. 
Local Government Association of Queensland (LGAQ) 2005, Size, Shape and Sustainability of Queensland Local Government, Discussion Paper, Local Government Association of Queensland, Brisbane.

Local Government Association of Queensland (LGAQ) 2006, Size, Shape and Sustainability: Guidelines Kit, Local Government Association of Queensland, Brisbane.

Local Government Association of Queensland (LGAQ) 2007, Submission to Local Government Reform Commission, Local Government Association of Queensland, Brisbane.

Local Government Association of Tasmania (LGAT) 2007, A Review of the Financial Sustainability of Local Government in Tasmania, Local Government Association of Tasmania, Hobart.

Mueller, D. C. (2003), Public Choice III, Cambridge University Press, Cambridge. Marris, S. 2007, 'Howard Overturns Beattie Council Laws', The Australian, 16 August.

Oakerson, R. J. 1999, Governing Local Public Economies, CS Press, Oakland.

Oates, W. 1972, Fiscal Federalism, Harcourt Brace, New York.

PriceWaterhouseCoopers (PWC) 2006, National Financial Sustainability Study of Local Government, PriceWaterhouseCoopers, Sydney.

Rouse, P., and M. Putterill 2005, 'Local Government Amalgamation Policy: A Highway Maintenance Evaluation', Management Accounting Research, vol. 16 , no. 4, pp.438-63.

Sancton, A. 2000, Merger Mania, McGill-Queens University Press, Montreal.

Soul, S. 2000, Population Size and Economic and Political Performance of Local Government Jurisdictions, unpublished Ph.D. thesis, Southern Cross University, Lismore.

Stansel, D. 2005, 'Local Decentralisation and Economic Growth: A Cross-Sectional Examination of US Metropolitan Areas', Journal of Urban Economics, 57(1), pp.55-72.

State of Queensland (Local Government Reform Commission) 2007, Report of the Local Government Reform Commission, Final Report, Local Government Reform Commission, Brisbane.

Vince, A. 1997, 'Amalgamations', in B. E. Dollery and N. A. Marshall (eds), Australian Local Government: Reform and Renewal, Macmillan, Melbourne, pp.151-71.

Western Australian Local Government Association (WALGA) 2006, Systemic Sustainability Study: In Your Hands - Shaping the Future of Local 
Agenda, Volume 15, Number 1, 2008

Government in Western Australia, Western Australian Local Government Association, Perth. 